\title{
PERIODONTAL DISEASE AMONGST INDIAN GERIATRIC POPULATION - A REVIEW
}

Col S. K. Rath ${ }^{1}$, P. C. Das ${ }^{2}$

\section{HOW TO CITE THIS ARTICLE:}

Col S. K. Rath, P. C. Das. "Periodontal Disease amongst Indian Geriatric Population - A Review". Journal of Evolution of Medical and Dental Sciences 2014; Vol. 3, Issue 11, March 17; Page: 2732-2739,

DOI: $10.14260 /$ jemds/2014/2201

\begin{abstract}
There has been increasing attention paid in recent years to the periodontal disease diagnosis, management and prevention in elderly patients. It is an established fact that advancement in age per se predisposes to periodontal disease and also certain systemic conditions of old age have been strongly interlinked with periodontal disease. However, the studies and data on periodontal disease in Indian geriatric population are limited, despite increasing number of elderly patients with varied dental problems day by day. This paper aims to assess and review the prevalence and patterns of periodontal disease of older Indians and their treatment needs through literature reviews with the use of common search engines such as "Google Scholar" and "Pub Med". Also, it reviews the current oral health services of India with considerations for developments in them.
\end{abstract}

KEYWORDS: Periodontitis; Geriatric population; India.

INTRODUCTION: Approximately 600 million people worldwide are aged 60 years and over which will double by the year 2025. By 2050, it will be 2 billion; $80 \%$ people are living in developing countries.1,2 Poor oral health among old aged people is an important public health issue and is a growing burden to countries worldwide. ${ }^{1}$ One of the reasons is lack of epidemiological data to identify areas needing oral health care. There also prevails a view that people in Asia are particularly susceptible to periodontitis. This view of a particularly high prevalence of periodontal diseases appears to have originated from early epidemiological studies using an index system that gave weight to gingivitis and moderate periodontitis resulting from poor oral hygiene and calculus deposition. ${ }^{3}$ Albandar et al. ${ }^{4}$ in an overview concluded that subjects of Asian ethnicity had the third highest prevalence of periodontitis.

One of the success stories of India is increase in life expectancy leading to rapid population aging. India has around 100 million elderly at present and the number is expected to increase to 323 million, constituting 20 per cent of the total population, by 2050.5 The rapid graying of the population comes with a number of difficulties in terms of general and oral health. Multimorbidity, malnutrition. Poor social and public health care support are the main reasons for increasing prevalence of disabilities in this age group. If the impairment is severe enough; they may not be able to leave the house without assistance or may become institutionalized in the nursing homes. The two striking features regarding the elderly population of India are as follows: (i) the rate of growth of the elderly population is much faster than the growth of the total population; and (ii) the feminization of the elderly population. ${ }^{6}$ Oral health is linked to overall health, happiness, and general well-being of the individual.

The extent and severity of periodontal diseases was shown to be different in different age groups and the general trend observed in majority of the studies was increasing severity with increasing age. ${ }^{7-12}$ Ageing is a natural process and hence age related structural and functional 
changes occur in oral cavity, salivary glands and dental structures. Along with, there is decline host immunity against disease process. But if one can practice optimum oral hygiene, he or she can maintain teeth throughout life. Increasing severity may be because of the untreated cumulative effect of disease process over the period of time.

This paper aims to assess the prevalence and patterns of periodontal disease of older Indians and their treatment needs through literature reviews with the use of common search engines such as "Google Scholar "and "Pub Med". Also, it reviews the current oral health services of India with considerations for developments in them.

PERIODONTAL TISSUE CHANGES IN ELDERLY: The thinning and decreasing in the keratinization of the gingival epithelium may occur with aging and may indicate an increase in tissue permeability and a decrease in its resistance to infection and trauma. ${ }^{13}$ The apical migration of the junctional epithelium, with consequent gingival recession occurs. Although such a migration is associated with aging, the loss of insertion caused by aging alone may not seem to have clinical significance. ${ }^{1}$ Apparently, gingival recession is not an avoidable physiological process caused by aging, but a cumulative and progressive effect from periodontal disease or trauma over time. There is a reduction in the number of total cells in the connective tissue and a consequent reduction in collagen synthesis. ${ }^{6}$ There is a reduction in the number of fibroblasts in the periodontal ligament and also in its functional activity, which includes the mitotic and synthesis ability. There is also a reduction in the organic matrix production and in vascularization and an increase in the number of elastic fibers. ${ }^{4,14} \mathrm{~A}$ continuous deposition of cementum was observed, which leads to an increase in thickness of this tissue with age, mainly in the teeth apical region to compensate for the physiological wear of teeth. ${ }^{15}$ Radiographic exams revealed that the mean alveolar bone height was reduced in older patients in a population ranging from 20 to $>80$ years of age. 16 This reduction in height may be due to systemic factors instead of being due to age-related alterations. ${ }^{13}$ The induction of gingivitis in subjects of different age groups and with healthy periodontium showed a similar plaque accumulation in old and young adults. Nevertheless, old adults developed a more severe gingivitis and with a greater number of inflammatory cells, demonstrating an infiltrate with a greater proportion of B cells and lower density of polymorphonuclear cells ${ }^{17}$. This situation reveals possible effects of aging on the quality of the immune response.

The associations between dental disease and specific medical conditions are becoming more established.18 Oral health is not only important to the appearance and sense of well-being, but also to general body health and quality of life in elderly individuals. Oral diseases are complex, multifactorial and progressive in nature. Improving the oral health will significantly enhance the physical, social and mental attributes of geriatric individuals at home or work place. Third, recent interest in the relationship between oral infection/periodontal disease and systemic diseases (cardiovascular /cerebrovascular disease, diabetes mellitus, and respiratory diseases) has particular relevance for older individuals since many of these relationships disproportionally affect the elderly. Meurman and Hamalainen ${ }^{19}$ observed that oral infections have a more profound effect upon the elderly compared to other segments of the population.

\section{HISTORICAL STUDIES REGARDING PERIODONTAL DISEASE INCIDENCE IN INDIA:}

Greene ${ }^{14}$ conducted one of the very earliest prevalence studies in India. The periodontal index (Russell, 1956) ${ }^{20}$ was used. The survey was on the school population in a low socio economic area. 
Ninety-seven per cent of the 11-17 year old persons examined had overt evidence of periodontal disease, while fewer than 2 percent of the total had obvious periodontal pockets. All the 63 persons over 17 years of age had overt gingival inflammation, and 19persons (30.2\%) per cent, had obvious periodontal pockets. Persons with obvious periodontal pocket (periodontitis) were $0.2 \%$ in 11 yrs., 0.4 in 13 years, $1 \%$ in 15 and $6 \%$ in 17 years group. Ramfjord ${ }^{15}$ observed that there is $100 \%$ prevalence of periodontal disease (including gingivitis) in India. At 17 years $10 \%$ of Indian boys had periodontitis. This periodontitis was due to accumulation of calculus, plaque and debris rather than due to age, sex, geography, economic status or nutrition. Sanjana et. Al ${ }^{16}$ did a study on Bombay residents in 1956. 83.2\% had signs of periodontal disease. However, none of the above study at National level has focused on the prevalence of periodontal disease in geriatric population.

What is quite clear is that the prevalence of periodontitis increases with age. A study by Dye and Selwitz ${ }^{21}$ examined the relationship between a number of different periodontitis severity indices and risk factors for periodontitis. For all periodontal indices, older age ( $\geq 40$ years), lower level of education, a history of cigarette smoking, male gender and being a non-Hispanic black were associated with increased severity of periodontitis. This study also identified an interesting interaction between aging and smoking; these two risk factors appeared to act synergistically to increase the risk for periodontitis.

Holm-Pedersen 22 and colleagues from Sweden reported on the periodontal status of community-dwelling individuals who were at least 80 years of age. There were a total of 159 participants, and 30(19\%) were edentulous. Of the remaining 129 subjects, 121 received a periodontal examination. The average number of teeth present was 16.3. The criteria for 'serious' periodontitis were at least four sites with clinical attachment loss of at least $5 \mathrm{~mm}$, with at least one site having a probing depth of $4 \mathrm{~mm}$ or more. With that case definition, $50.5 \%$ of the population demonstrated severe periodontitis. Similar studies have been conducted in other countries. A study of the periodontal status and the need for periodontal treatment has been reported for persons 7686 years of age in Finland ${ }^{23}$. A total of 364 individuals were examined and $46.2 \%$ were edentulous. Of the 175 dentate individuals, the mean number of teeth was 15.1 for men and 14.0 for women. Using the Community Periodontal Index of Treatment Needs (CPITN), 11\% of the subjects had one or more sites with a probing depth of $6 \mathrm{~mm}$ or more (CPITN $=4)$. The majority of teeth that were missing were molars.

\section{PERIODONTAL DISEASE PREVALENCE IN INDIAN GERIATRIC POPULATION:}

National Oral Health Survey and Flouride Mapping, 2002-200324, Dental Council of India, New Delhi, 2004: this is the first ever national level epidemiological survey done in India. The survey was to collect information covering various dimensions of oral health including prevalence of oral health problems. Community Periodontal Index (CPI) was used for disease assessment. The prevalence of periodontal disease increased with age. Moderate periodontitis was seen in $17.5 \%$ of the 35-44 years group; and $21.4 \%$, in the 65-74 years group; whereas severe disease, defined as at least one tooth with $\geq 6 \mathrm{~mm}$ probing depth, was seen in $7.8 \%$ in the $35-44$ years group and $18.1 \%$ in the $65-74$ years group. No marked gender differentials were observed and marginally higher prevalence seen in rural subjects.

Under the Government of India and World Health Organization collaborative program on oral health, a Multicentric oral health survey was envisaged in the year 200425, in order to have a baseline 
data of the oral diseases burden and associated risk profile of the population for four index age group i.e. 12, 15, 35-44 and 65-74 years. This survey was conducted in seven different geographical locations in India i.e. Arunachal Pradesh, Delhi, Maharashtra, Puducherry, Rajasthan, Orissa and Uttar Pradesh. WHO probe was used for periodontal measures, and CPI index was used for disease assessment. The loss of attachment ( $3 \mathrm{~mm}$ or more) was $96 \%$ in 65-74 years old in Maharashtra. The prevalence of Loss of attachment was significantly higher in 65-74 years age group compared to 3544 yrs. group. The highest prevalence in 65-74 years group was recorded from Maharashtra (96\%), followed by Orissa (90\%), Delhi (85.5\%), Rajasthan (75\%), Uttar Pradesh (68\%) and Puducherry (55\%). Arunachal Pradesh recorded the lowest prevalence of 20\%. The general trend for loss of attachment observed was that it was higher in rural than in urban population and was higher in males compared to females. "Cleaning teeth regularly" group showed significantly reduced prevalence of periodontal disease, while use of toothbrush was found to be significantly better than finger cleaning. The survey was basically a prevalence survey with less emphasis on risk factors. This survey gave a reliable baseline data at the national and state levels.

Jagadeesan et al ${ }^{26}$ did a systematic random sampling of rural women in Puducherry. The prevalence of moderate periodontitis increased with age; the risk of being affected by periodontitis was 2.3 times for persons above 35 years of age than below. Shah ${ }^{27}$ in her report for the National Commission on Macroeconomics and Health (NCMH) observed that for periodontal diseases, the projection is alarming, with prevalence at present being $45 \%$ for $15+$ years group, and the actual prevalence in lakhs will be 2957.6 (year 2000), 3190.2 (year 2005), 3413.8 (year 2010) and 3624.8 (year 2015). Due to the rampant use of paan masala and ghutka by persons of all age groups and both the sexes, periodontal disease prevalence will be higher than projected. If minor periodontal diseases are included, the proportion of population above the age of 15 years with this disease could be $80 \%$ to $90 \%$. Concerned with the urgent need for action, it is vital to promote sound oral health, prevention of dental caries and periodontal diseases and give impetus to activities that promote oral health, WHO had dedicated World Health Day 1994 to oral health. The objectives were to mobilize the dental health resources for promotive action and increase in basic research.

\section{STEPS TOWARDS IMPROVEMENT OF PERIODONTAL CARE TO ELDERLY OF INDIA:}

Ageing is a natural process and changes are there in host immunity against disease process but if one can practice optimum oral hygiene, he or she can maintain teeth throughout life. Increasing severity may be because of the untreated cumulative effect of disease process over the period of time. The central focus of preserving the oral health of the elderly and the residents is to enable them to maintain adequate physical and psychosocial functions. In order to evaluate the oral health status of aged residents, significant data must be gathered, and they must be made available to those who need it. Measures should be developed to implement and improve the oral health care strategies in the elderly and to evaluate the effectiveness of these measures. Oral health should be incorporated into routine assessment by care staff, and the continuing dental care should be available to the residents. It is important to integrate the preventive, curative and educational oral health care program into the existing health and educational infrastructure. Comprehensive geriatric assessment (CGA) tool28, which is used by geriatric health care team to assess older patients in outpatient clinic and indoor settings, should incorporate the oral health components for early detection of periodontal disease, so that effective measures can be undertaken in time. There should be an easy access and timely 
approach to general and specialist dental services and to oral hygiene equipment appropriate to individual needs of older patients. Continuous dental education program must be organized to improve the knowledge, skills and attitudes of health professionals and health care workers regarding the oral health of the geriatric patients.

CONCLUSION: Old age ideally represents the later part of a person's life, having lived for a relatively long time or attained a specific age. Improvement in periodontal health is of paramount requirement for the improvement of general health as oral health is an integral part of overall health. Out of many issues concerning the quality of life in the elderly, oral health is one of the major issues. In elderly people, oral health contributes significantly towards quality of life. Poor oral health and loss of teeth not only adversely affect the dietary intake, nutritional status and phonetics, but also compromise the general health. A number of factors are known to be associated with the oral health of the elderly, such as socio economic status, literacy level, marital status, smoking or chewing tobacco and alcohol consumption. Nationwide multiple multicentric epidemiological study is the need of the time which will certainly help in identifying and formulating a perfect periodontal treatment and preventive protocol.

\section{REFERENCES:}

1. United Nations Population Division. World Population Prospects: The 2002 Revision, New York, USA. United Nations 2003; 1-36.

2. World Health Organization. Active Ageing: A Policy Framework. Geneva: World Health Organization 2002; 1-60.

3. Corbet, E. F. Periodontal diseases in Asians. Journal of the International Academy of Periodontology 8.4 (2006): 136-144.

4. Albandar JM, Rams TE. Global epidemiology of periodontal diseases: An overview. Periodontology 2000 2002; 29:7-10.

5. United Nations Population Fund (UNFPA) and Help Age International Report: 2012.

6. Chandra S, Chandra S. Geriatric Dental health Care. Text Book of Community Dentistry, 1st Ed. New Delhi: Jaypee Brothers Medical Publishers.

7. Shah N. Oral health care system for elderly in India. Geriatr Gerontol Int 2004; 4:S162-4.

8. Kumar TS, Dagli RJ, Mathur A, Jain M, Balasubramanyan G, Prabhu D, et al. Oral health status and practices of dentate Bhil adult tribes of southern Rajasthan, India. Int Dent J 2009; 59(3):133- 140.

9. Kumar S, Dagli RJ, Chandrakant D, Prabu D, Suhas K. Periodontal status of green marble mine labourers in Kesariyaji, Rajasthan, India. Oral Health Prev Dent 2008; 6(3):217-221.

10. Vandana KL, Reddy MS. Assessment of periodontal status in dental fluorosis subjects using community periodontal index of treatment needs. Indian J Dent Res 2007; 18(2):67-71.

11. Anuradha KP, Chadrashekar J, Ramesh N. Prevalence of periodontal disease in endemically flourosed areas of Davangere Taluk, India. Indian J Dent Res 2002; 13(1):15-19.

12. Thomas S, Tandon S, Nair S. Effect of dental health education on the oral health status of a rural child population by involving target groups. J Indian Soc Pedod Prev Dent 2000; 18(3):115-125.

13. Robert GH, Barry C. Practical Consideration in special patient Care, Delivering dental care to nursing home and homebound patients. Dent Clin North Am 1994; 38:537-51. 
14. Greene. J.C. Periodontal Disease in India: Report of an Epidemiological Study. Journal of Dental Research 1960; 39:302-312.

15. Ramfjord S.P, Emslie, Greene J.C, Held and Waerhaug.J. Epidemiological Studies of Periodontal Diseases. American Journal of Public Health 1968; 58(9):17-22.

16. Sanjana M.K., Mehta F.S., Doctor R.H. and Baretto M.A. Mouth Hygiene Habits and Their Relation To Periodontal Disease Journal of Dental Research 1956; 35:645-47.

17. Shah N, Pandey RM, Duggal R, Mathur VP, Rajan K. Oral Health in India: A report of the multi centric study, Directorate General of Health Services, Ministry of Health and Family Welfare, Government of India and World Health Organisation Collaborative Program, December 2007

18. Clark CA, Vanek EP. Meeting the health care needs of people with limited access to care. J Dent Educ 1984; 48: 213-216.

19. Meurman J.H. \& P. Hamalainen (2005). Oral health and morbidity - implications of oral infections on the elderly. Gerodontology 23 (1), 3-16.

20. Russell A. L. A system of classification and scoring for prevalence surveys of periodontal disease. Journal of Dental Research 35.3 (1956): 350-359.

21. Dye, Bruce A., and Robert H. Selwitz. The relationship between selected measures of periodontal status and demographic and behavioural risk factors. Journal of clinical periodontology 32.7 (2005): 798-808.

22. Holm-Pedersen P, Russell S.L, Arlund K, Viitanen M, Wimblad B. \& R.V. Katz(2006a). Periodontal disease in the oldest-old living in Kungsholmen, Sweden: findings from the KEDHS project. Journal of Clinical Periodontology 33 (6), 376-384.

23. Ajwani S. \& A. Ainamo. Periodontal conditions among the old elderly: five-year longitudinal study. Special Care in Dentistry 21 (2), 45-51.

24. Bali Mathur, Talwar Chanana. National Oral Health Survey and Flouride Mapping 2002-2003. India. Dental Council of India, New Delhi, 2004.

25. Naseem Shah, Pandey R.M. et al. Oral Health in India: A report of the multi centric study, Directorate General of Health Services, Ministry of Health and Family Welfare, Government of India \& World Health Organisation Collaborative Program, December 2007.

26. Jagadeesan M, Rotti SB, Dananbalan M. Oral Health status and risk factors for dental and periodontal diseases among rural women in Pondicherry. Indian Journal of Community Medicine 2000; XXV(1):31-38.

27. Naseem Shah. Oral and dental diseases: Causes, prevention and treatment strategies In NCMH Background Papers-Burden of Disease in India (New Delhi, India), September 2005, National Commission on Macroeconomics and Health, Ministry of Health \& Family Welfare, Government of India, New Delhi September 2005, 275-298.

28. D. Solomon, A.S. Brown, K. Brummel-Smith et al. National Institutes of health Consensus Development Conference statement: geriatric assessment methods for clinical decision-making. J Am Geriatr Soc, 36 (1988), pp. 342-347. 


\begin{tabular}{|c|c|c|c|c|c|}
\hline Year & Author & $\begin{array}{l}\text { Sample } \\
\text { size }\end{array}$ & Population & $\begin{array}{c}\text { Age } \\
\text { range }\end{array}$ & Prevalence \\
\hline 2004 & Bali et al24 & $\begin{array}{l}310 \text { per } \\
\text { region }\end{array}$ & $\begin{array}{l}\text { Urban and } \\
\text { rural }\end{array}$ & $\begin{array}{l}5,12,35- \\
44,65- \\
74 \\
\text { groups }\end{array}$ & $\begin{array}{l}17.5 \% \text { moderate } \& 7.8 \% \text { severe } \\
\text { periodontitis ( } 35-44 \text { years) } \\
21.4 \% \text { moderate and } 18.1 \text { severe } \\
\text { periodontitis (65-74years) }\end{array}$ \\
\hline 2007 & $\begin{array}{l}\text { WHO25 } \\
\text { Arunachal } \\
\text { Pradesh }\end{array}$ & 3200 & $\begin{array}{l}\text { Field } \\
\text { survey }\end{array}$ & $\begin{array}{c}\text { 12, 15, } \\
35-44, \\
65-74 \\
\text { Age } \\
\text { group. }\end{array}$ & $\begin{array}{l}15 \% \text { moderate and } 2.6 \text { severe } \\
\text { periodontitis ( } 35-44 \text { years), } 18 \% \\
\text { moderate and } 0.6 \% \text { severe } \\
\text { periodontitis ( } 65-74 \text { years) }\end{array}$ \\
\hline 2007 & $\begin{array}{l}\text { WHO25 } \\
\text { Delhi }\end{array}$ & 3200 & $\begin{array}{l}\text { Field } \\
\text { survey }\end{array}$ & $\begin{array}{c}12,15, \\
35-44, \\
65-74 \\
\text { Age } \\
\text { group. }\end{array}$ & $\begin{array}{l}34 \% \text { mod and } 1.0 \% \text { severe in } 35-44, \\
1.7 \% \text { mod and } 1.7 \% \text { severe in } 65-74 \\
\text { age groups. }\end{array}$ \\
\hline 2007 & $\begin{array}{c}\mathrm{WHO}^{25} \\
\text { Maharashtra }\end{array}$ & 3200 & $\begin{array}{l}\text { Field } \\
\text { survey }\end{array}$ & $\begin{array}{c}12,15, \\
35-44, \\
65-74 \\
\text { Age } \\
\text { group }\end{array}$ & $\begin{array}{l}48 \% \text { moderate and } 2.9 \% \text { severe } \\
\text { periodontitis ( } 35-44 \text { years), } 55.2 \% \\
\text { moderate and } 4.5 \% \text { severe } \\
\text { periodontitis ( } 65-74 \text { years) }\end{array}$ \\
\hline 2007 & $\begin{array}{l}\mathrm{WHO}^{25} \\
\text { Orissa }\end{array}$ & 3200 & $\begin{array}{c}\text { Field } \\
\text { survey }\end{array}$ & $\begin{array}{c}12,15, \\
35-44, \\
65-74 \\
\text { Age } \\
\text { group. }\end{array}$ & $\begin{array}{l}35.7 \% \text { moderate and } 9.7 \% \text { severe } \\
\text { periodontitis ( } 35-44 \text { years), } 42 \% \\
\text { moderate and } 15.6 \% \text { severe } \\
\text { periodontitis ( } 65-74 \text { years) }\end{array}$ \\
\hline 2007 & $\begin{array}{l}\text { WHO25 } \\
\text { Puduchery }\end{array}$ & 3200 & $\begin{array}{l}\text { Field } \\
\text { survey }\end{array}$ & $\begin{array}{c}12,15, \\
35-44, \\
65-74 \\
\text { Age } \\
\text { group. }\end{array}$ & $\begin{array}{l}26.3 \% \text { moderate and } 4.7 \% \text { severe } \\
\text { periodontitis ( } 35-44 \text { years) }\end{array}$ \\
\hline 2007 & $\begin{array}{l}\mathrm{WHO}^{25} \\
\text { Rajasthan }\end{array}$ & 3200 & $\begin{array}{l}\text { Field } \\
\text { survey }\end{array}$ & $\begin{array}{c}12,15, \\
35-44, \\
65-74 \\
\text { Age } \\
\text { group. }\end{array}$ & $\begin{array}{l}48 \% \text { moderate and } 2 \% \text { severe } \\
\text { periodontitis ( } 35-44 \text { years) }\end{array}$ \\
\hline 2007 & $\begin{array}{c}\mathrm{WHO}^{25} \\
\text { Uttar Pradesh }\end{array}$ & 3200 & $\begin{array}{l}\text { Field } \\
\text { survey }\end{array}$ & $\begin{array}{c}12,15, \\
35-44, \\
65-74 \\
\text { Age } \\
\text { group. }\end{array}$ & $\begin{array}{l}23.5 \% \text { moderate periodontitis } \\
(35-44 \text { years), } 34.5 \% \text { moderate and } \\
14 \% \text { severe }(65-74 \text { years }) .\end{array}$ \\
\hline
\end{tabular}

Table 1: Prevalence data of periodontitis in Older Indians 


\section{REVIEW ARTICLE}

\section{AUTHORS:}

1. Col S. K. Rath

2. P.C. Das

\section{PARTICULARS OF CONTRIBUTORS:}

1. Senior SPL, Army Dental Centre, R \& R Hospital, Delhi Cantt., New Delhi.

2. Assistant Professor, Department of Geriatric Medicine, All India Institute of Medical Sciences, New Delhi.

\section{NAME ADDRESS EMAIL ID OF THE} CORRESPONDING AUTHOR:

Dr. P. C. Das,

Assistant Professor,

Department of Geriatric Medicine,

All India Institute of Medical Sciences, Ansari Nagar, New Delhi - 110029.

E-mail: purnadas2010@gmail.com

Date of Submission: 18/02/2014.

Date of Peer Review: 19/02/2014.

Date of Acceptance: 28/02/2014.

Date of Publishing: 11/03/2014. 